\title{
Inclusion Modification in Si-Mn Killed Steels using Titanium Addition
}

\author{
Vivek THAPLIYAL, ${ }^{*}$ Abhishek KUMAR, David ROBERTSON and Jeffrey SMITH \\ Materials Science and Engineering, Missouri University of Science \& Technology, 223, McNutt Hall, 1400 N Bishop, Rolla, MO, \\ 65409-0340 USA.
}

(Received on September 18, 2014; accepted on October 24, 2014)

\begin{abstract}
Modification of inclusions by titanium (Ti) additions in low-alloyed Si-Mn killed steels was studied. Formation of the modified inclusions was studied by measuring the inclusion count and chemistry. Mn-Si$\mathrm{Al}-\mathrm{S}-\mathrm{O}$ based inclusions were observed in the steel, after $\mathrm{Si}-\mathrm{Mn}$ de-oxidation, to which ferro-titanium (FeTi) additions were made. Thermochemical software (FactSage) was used to study the equilibrium between steel and inclusions and subsequent modification due to Ti addition. Inclusion count and chemistry in the steel were measured at different time intervals after the FeTi additions. $\mathrm{MnO}-\mathrm{SiO}_{2}$ inclusions transformed to $\mathrm{TiO}_{2}-\mathrm{MnO}-\mathrm{SiO}_{2}$ based inclusions with $\mathrm{Ti}$ replacing both $\mathrm{Mn}$ and $\mathrm{Si}$ in the inclusions. Si removal was more prominent from the inclusions compared to $\mathrm{Mn}$. When more FeTi was added to the steel the inclusions further decreased in their $\mathrm{Mn}$ and Si content. With further FeTi addition Ti based inclusions with $\mathrm{Al}$ and $\mathrm{Mn}$ content less than 10\% and Si content less than 5\% were formed. MnS inclusions were also observed in the steel and formed as a result of segregation during solidification.
\end{abstract}

KEY WORDS: inclusion modification; ferro-titanium addition; thermodynamic modeling.

\section{Introduction}

Non-metallic inclusions are undesired particles that impact mechanical properties and surface quality of steel. They may also cause processing difficulties such as nozzleclogging and break-outs during casting. ${ }^{1,2)}$ Inclusions need to be removed or modified to achieve optimal steel properties. The main objective of inclusion modification techniques is to convert existing solid inclusions to liquid inclusions that can either be removed by coalescence and floatation or deformed in the solidified steel. ${ }^{3-6)}$ Further, liquid inclusions would be easy to deform thus preventing failure during casting. The inclusions that were liquid may be solid at deformation temperatures but being round in shape as solids would cause fewer problems during deformation. ${ }^{3,7)}$ Calcium treatment in aluminum-killed steels is a known technique for the modification of solid $\mathrm{Al}_{2} \mathrm{O}_{3}$ inclusions to form liquid calcium aluminate inclusions. ${ }^{2,8,9)}$

In the past, several techniques have been employed for inclusion modification and removal. Liquid inclusions coalesce to form larger inclusions and are easier to remove. These inclusions can attach to refractory surfaces or get entrapped by the liquid slag. Slag properties can be optimized in order to enhance the entrapment and absorption of non-metallic inclusions. ${ }^{10)}$ Argon bubbling, ${ }^{11,12)}$ magnetic stirring, ${ }^{13)}$ and optimization of top slag, ${ }^{1,4,10)}$ are ways to remove inclusions. Inclusion floatation occurs because of differences between densities of non-metallic inclusions and molten steel, however many inclusions are too small for the floatation to be effective. It is important for these small inclusions to coalesce and become larger in order to float. Electromagnetic or gas stirring can increase inclusion coalescence/agglomeration and floatation. Inclusions can be

* Corresponding author: E-mail: vtty6@mst.edu

DOI: http://dx.doi.org/10.2355/isijinternational.55.190 modified by adding materials ( $\mathrm{Ca}$, Ti etc.), which chemically combine with the existing inclusions to form liquids at steel making temperatures (1823-1923 K). ${ }^{1)}$

$\mathrm{Si}-\mathrm{Mn}$ de-oxidation is widely used in steelmaking prior to casting. It has an advantage over aluminum de-oxidation in that the primary inclusions are generally liquid. ${ }^{14)}$ In SiMn killed steels, expected inclusions are a combination of $\mathrm{MnO}, \mathrm{SiO}_{2}$ and $\mathrm{Al}_{2} \mathrm{O}_{3}{ }^{15)}$ Impurities in the ferro-alloys and refractories are the sources of $\mathrm{Al}_{2} \mathrm{O}_{3}$ in these inclusions.

Figure 1 shows $\mathrm{SiO}_{2}-\mathrm{TiO}_{2}-\mathrm{MnO}$ phase diagram plotted using FactSage ${ }^{16)}$ at $1523 \mathrm{~K}$ and oxygen partial pressure of $10^{-5}$ atm. Kang et al. reported that $\mathrm{SiO}_{2}-\mathrm{TiO}_{2}-\mathrm{MnO}$ phase equilibria depends on the oxygen potential. ${ }^{17)}$ While plotting the ternary diagram the oxygen partial pressure was varied

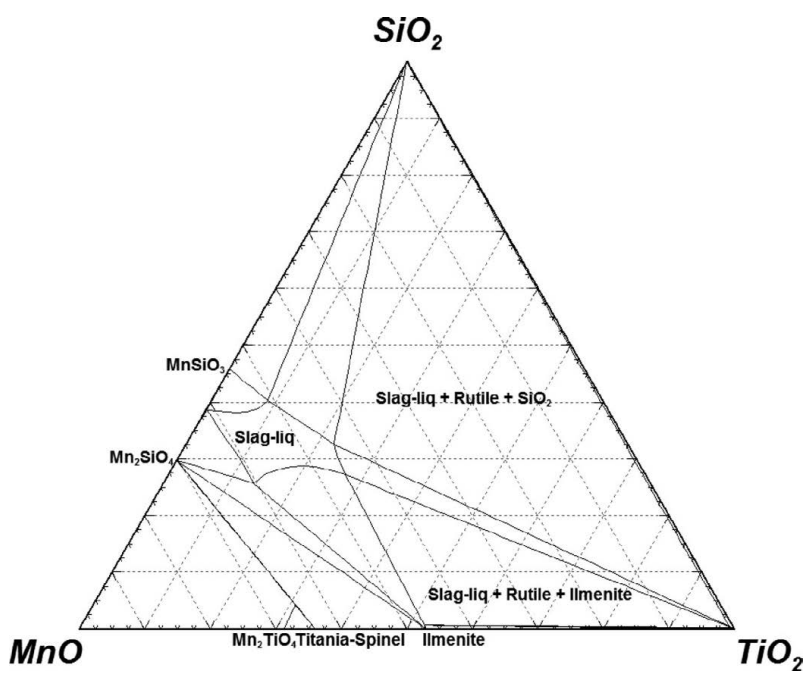

Fig. 1. $\mathrm{MnO}-\mathrm{SiO}_{2}-\mathrm{TiO}_{2}$ phase diagram plotted at $1523 \mathrm{~K}$ and $\mathrm{P}_{\mathrm{o}_{2}}=$ $10^{-5}$ atm using FToxid - FACT oxide database of FactSage. ${ }^{16}$ 
between $10^{-5}-0.21 \mathrm{~atm}$ (expected in this study) but no significant difference was observed. The ternary diagram shows the liquid phase region (Slag-liq) enlarged by the addition of $\mathrm{TiO}_{2}$ to $\mathrm{MnO}-\mathrm{SiO}_{2}$ binary system. Amitani et al. report similar behavior at $1573 \mathrm{~K}$ and $1773 \mathrm{~K} .{ }^{18)}$ Thus, the use of FeTi after $\mathrm{Si}-\mathrm{Mn}$ de-oxidation has the potential to form liquid inclusions with an even lower melting point and ease the inclusion removal process. The purpose of this study was to determine the effect of $\mathrm{Ti}$ on the evolution of inclusion composition, size and removal. Inclusion modification can also be used to help precipitate target phases in the solid state by providing the necessary precipitation sites - socalled "Oxide Metallurgy". ${ }^{19)}$ Ti-addition has been studied by researchers to modify $\mathrm{MnO}-\mathrm{SiO}_{2}$ inclusions and enhance MnS precipitation. ${ }^{18,20)}$ These precipitates work as nuclei for inter-granular ferrite formation from austenite. ${ }^{18,20)}$

In the present study inclusion modification in low-alloy $\mathrm{Si}-\mathrm{Mn}$ de-oxidized steel using $\mathrm{Ti}$ addition was studied. Inclusion chemistry and morphology variation were evaluated as a function of the amount of Ti added as well as time after addition. The modification was modeled using thermodynamic software FactSage $6.4^{16)}$ and the calculations were compared to the experimental values.

\section{Experimental Procedure}

Experiments were conducted in an induction furnace with a crucible of size $10 \mathrm{~cm}$ internal diameter and $20 \mathrm{~cm}$ height. Induction iron $(7 \mathrm{~kg})$ was melted and ferro-alloy additions were made. Temperature of liquid steel was maintained around $1873 \mathrm{~K}( \pm 5 \mathrm{~K})$. Argon was blown at the rate of 1 liter/min over the liquid steel and under a refractory blanket to minimize oxidation.

The initial chemistry of the induction iron is shown in Table 1. Ferro-silicon (Fe75Si) and ferro-manganese (FeMn) additions were made to de-oxidize the induction iron and form steel (Table 1) containing $\mathrm{MnO}-\mathrm{SiO}_{2}$ based inclusions. Total oxygen in the steel after the Fe75Si + FeMn addition was measured to be 170 ppm (0.017 wt.\%) using $\mathrm{O}$ and $\mathrm{N}$ analyzer based on inert gas fusion principle.

Table 1. Initial chemistry of induction iron and steel (after $\mathrm{Mn}-\mathrm{Si}$ addition) used for the experiment (balance Fe) measured using arc-spectroscopy.

\begin{tabular}{ccccccccccc}
\hline Wt.\% & $\mathrm{C}$ & $\mathrm{Si}$ & $\mathrm{Mn}$ & $\mathrm{P}$ & $\mathrm{S}$ & $\mathrm{Cr}$ & $\mathrm{Ni}$ & $\mathrm{Al}$ & $\mathrm{Cu}$ & $\mathrm{Ti}$ \\
\hline Induction iron & - & - & 0.21 & 0.04 & 0.01 & 0.07 & 0.04 & 0.004 & 0.04 & - \\
Steel & 0.03 & 0.13 & 0.68 & 0.04 & 0.01 & 0.06 & 0.04 & - & 0.04 & - \\
\hline
\end{tabular}

Table 2. Ferro-alloy compositions used for this study (balance Fe).

\begin{tabular}{ccccccccc}
\hline Wt. $\%$ & $\mathrm{C}$ & $\mathrm{Si}$ & $\mathrm{S}$ & $\mathrm{Mn}$ & $\mathrm{P}$ & $\mathrm{Ca}$ & $\mathrm{Al}$ & $\mathrm{Ti}$ \\
\hline Fe75Si & $<0.1$ & $73-78$ & $<0.02$ & - & $<0.04$ & $<0.6$ & $<1.5$ & - \\
FeMn & 0.078 & 0.28 & 0.025 & 97.08 & 0.026 & - & - & - \\
FeTi & 0.1 & 0.1 & 0.01 & 0.2 & 0.01 & - & 0.2 & 70 \\
\hline
\end{tabular}

FeTi additions were made to the deoxidized steel and the impact on inclusions was analyzed. Compositions of all the ferro-alloys used in this study are shown in Table 2.

Multiple FeTi additions were made to the liquid steel and samples were taken at different time intervals. Table 3 shows the sampling chart for the samples taken during the experiment along with additions made.

Samples were analyzed using arc spectroscopy to measure steel chemistry at each sampling step. Combustion technique was used to measure the sulfur content of steel. Inclusion chemistry and morphology were studied using automated scanning electron microscopy (ASPEX).

\section{Thermodynamic Modeling of Inclusion Transforma- tion}

Data for inclusion chemistry, obtained from SEM-EDS, was used for modeling inclusion transformation with FeTi additions. Composition of the inclusions in terms of $\mathrm{Al}, \mathrm{Ca}$, $\mathrm{Mn}, \mathrm{S}, \mathrm{Si}$ and Ti was obtained from SEM-EDS, whereas, Fe and $\mathrm{O}$ concentration could not be measured accurately using this method. So, the oxygen was calculated stoichiometrically assuming primary oxides for the elements selected. For Ti, a 2:1 molar combination of $\mathrm{TiO}_{2}$ and $\mathrm{Ti}_{2} \mathrm{O}_{3}\left(\mathrm{TiO}_{1.75}\right)$ was assumed, which was similar to that calculated by thermodynamic software. The oxygen value was also adjusted for the sulfur content in the inclusion by balancing oxygen and sulfur anions to the metal cations. Inclusions were divided into major categories based on the prime components and further sub-divided into sub-types based on the composition range. For each of the sub-types, average inclusion chemistry was calculated. This averaged data was used along with the steel chemistry for equilibrium calculations.

Equilibrium calculations were carried out at $1873 \mathrm{~K}$ using thermodynamic software FactSage 6.4. To assess whether a given sub-type of inclusion was in equilibrium with the steel, it was reacted with the steel and the compo-
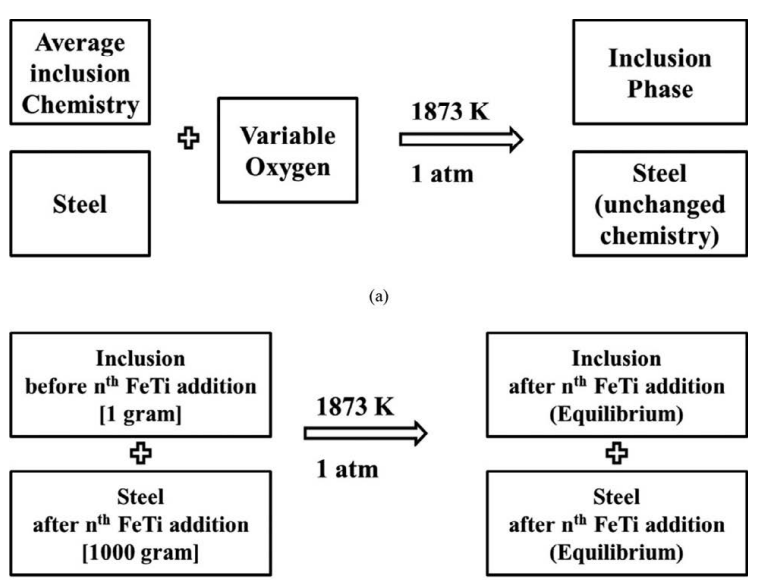

Fig. 2. Representation of thermodynamic FactSage model (a) to determine inclusion-steel equilibrium and (b) to determine inclusion transformation with FeTi addition for $\mathrm{n}=1,2$ or 3 .

Table 3. Sampling Chart.

\begin{tabular}{ccccc}
\hline Time of addition & Additions & Sample A & Sample B & Sample C \\
\hline 0 min & $17 \mathrm{~g} \mathrm{Fe} 75 \mathrm{Si}+38 \mathrm{~g} \mathrm{FeMn}$ & $+2 \mathrm{~min}$ & $+5 \mathrm{~min}$ & \\
$10 \mathrm{~min}$ & $\mathrm{Si}(0.18 \mathrm{wt} . \%), \mathrm{Mn}(0.53 \mathrm{wt} . \%)$ & & & \\
$20 \mathrm{~min}$ & $2 \mathrm{~g} \mathrm{FeTi}, \mathrm{Ti}(0.02 \mathrm{wt} . \%)$ & $+1 \mathrm{~min}$ & $+3 \mathrm{~min}$ & $+5 \mathrm{~min}$ \\
$30 \mathrm{~min}$ & $3 \mathrm{~g} \mathrm{FeTi}, \mathrm{Ti}(0.02 \mathrm{wt} . \%)$ & $+1 \mathrm{~min}$ & $+3 \mathrm{~min}$ & $+5 \mathrm{~min}$ \\
\hline
\end{tabular}


sition change was monitored. The stability (equilibrium with steel) of each inclusion sub-type was studied using the "Equilib" module of FactSage, considering the steel, slag, solid-solutions, and all possible liquids and solids as the possible phases. The databases used in this study were: FSstel (compound and solution database for steel), FactPS (gas species, solid and liquid compound database) and FToxid (compounds and solutions for oxide databases, with $\mathrm{S}$ in the oxide slags). The ratio of steel used for the equilibrium calculation per $100 \mathrm{~g}$ of inclusion was also varied. Based on the composition, steel to inclusion ratio of 1000:1 was selected. As $\mathrm{Fe}$ and $\mathrm{O}$ content of the inclusion were not measured accurately, any transfer of $\mathrm{Fe}$ and $\mathrm{O}$ from the steel to inclusion was allowed. However, any significant transfer from the inclusion phase to the steel indicated the non-equilibrium (instability) of the inclusion phase. Figure 2(a) shows a representation of the FactSage model used to determine inclusion-steel equilibrium. To study inclusion modification with Ti addition, its local equilibrium with steel was modeled. For each of these calculations $1 \mathrm{~g}$ of inclusion, of chemistry measured before addition, was reacted with $1000 \mathrm{~g}$ of steel of chemistry measured immediately after each addition as shown in Fig. 2(b).

\section{Results and Discussion}

Inclusion behavior and transformation were studied by plotting inclusion chemistries obtained from SEM-EDS on a ternary diagram. The inclusion chemistries had 6 major components namely $\mathrm{Al}, \mathrm{Ca}, \mathrm{Mn}, \mathrm{S}, \mathrm{Si}$ and Ti. To plot the inclusion chemistries on a ternary diagram three major elements were selected. The fourth significant element was plotted using color scale where the color corresponds to concentration. The inclusions were plotted as circles where the size of each circle represented the inclusion size.

\subsection{Inclusions in Mn-Si Deoxidized Steel}

In the case of samples taken after the Fe75Si + FeMn addition, $\mathrm{Mn}, \mathrm{Si}$ and $\mathrm{S}$ were chosen as the three components for the ternary plot. Al was chosen as the fourth element for coloring the inclusion composition points. Few $\mathrm{Ca}$ rich inclusions $(\sim 3 \%)$ (Table 4$)$ were also observed in these samples, whereas Ti was observed as an impurity in the samples.

On the Mn-Si-S ternary plots shown in Fig. 3, inclusions measured after 2 and 5 minutes of the $\mathrm{Mn}-\mathrm{Si}$ addition $(\mathrm{Fe} 75 \mathrm{Si}+\mathrm{FeMn})$ are plotted. Minute difference can be observed in these plots indicating that the inclusion distri-

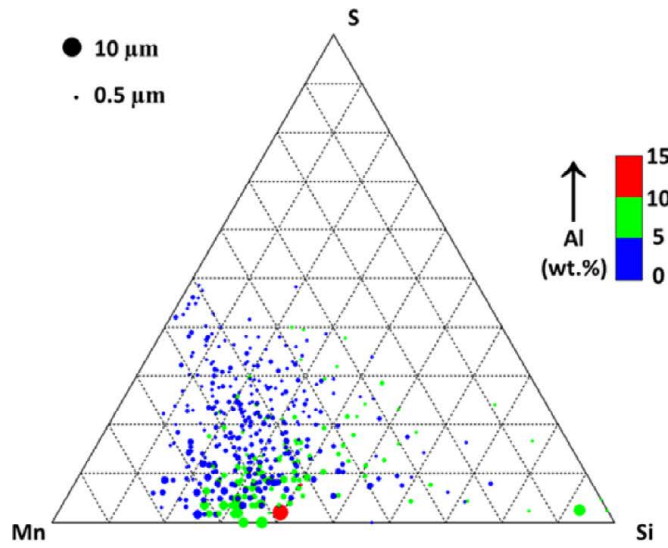

(a) After 2 minutes bution was stable after 2 minutes and behaved the same during mixing and solidification processes. There is also a "scatter" towards MnS that is common to all times, presumably due to $\mathrm{MnS}$ formation/precipitation in interdendritic liquid during solidification. This latter trend was observed to be independent of the sampling time. Based on the ternary diagram, Mn content in larger inclusions $(>3 \mu \mathrm{m})$ was almost constant $(50-60 \%)$. Most of these inclusions were oxides (Mn-Al-Si-O). The sulfur-rich inclusions were observed to be smaller $(<1 \mu \mathrm{m})$ in size. Average inclusion chemistries of the prominent inclusions observed in the steel 5 minutes after the $\mathrm{Mn}-\mathrm{Si}$ additions are summarized in Table 4.

As shown in Table 4, the inclusion population can be divided into three major categories namely: "oxides",

Table 4. Type of inclusions with analysis (wt.\%) observed after 5 minutes of $\mathrm{Fe} 75 \mathrm{Si}+\mathrm{FeMn}$ addition (balance $\mathrm{O}$, with $\mathrm{Ca}$ and $\mathrm{Ti}$ as minor species).

\begin{tabular}{|c|c|c|c|c|c|c|c|c|c|c|}
\hline \multirow{2}{*}{ Type } & \multirow{2}{*}{$\begin{array}{c}\text { Population } \\
\%\end{array}$} & \multirow{2}{*}{$\begin{array}{l}\text { Diameter } \\
(\mu \mathrm{m})\end{array}$} & \multicolumn{2}{|c|}{ S } & \multicolumn{2}{|c|}{$\mathrm{Mn}$} & \multicolumn{2}{|c|}{$\mathrm{Si}$} & \multicolumn{2}{|c|}{$\mathrm{Al}$} \\
\hline & & & $\min$ & $\max$ & $\min$ & $\max$ & $\min$ & $\max$ & $\min$ & $\max$ \\
\hline \multirow{5}{*}{ Oxide } & $3 \%$ & $2.3 \pm 1.6$ & 0 & 5 & 0 & 5 & 0 & 5 & 0 & 15 \\
\hline & $1 \%$ & $0.8 \pm 0.5$ & 0 & 5 & 0 & 5 & 35 & 45 & 5 & 15 \\
\hline & $8 \%$ & $1.4 \pm 0.5$ & 0 & 5 & 15 & 55 & 5 & 35 & 0 & 5 \\
\hline & $10 \%$ & $2.3 \pm 1.5$ & 0 & 5 & 15 & 45 & 15 & 35 & 5 & 15 \\
\hline & $6 \%$ & \multicolumn{9}{|c|}{ Other Compositions } \\
\hline \multirow{6}{*}{ Mixed } & $9 \%$ & $1.2 \pm 0.6$ & 5 & 15 & 15 & 45 & 15 & 25 & 0 & 5 \\
\hline & $3 \%$ & $0.9 \pm 0.2$ & 5 & 15 & 15 & 25 & 25 & 35 & 0 & 5 \\
\hline & $1 \%$ & $0.9 \pm 0.3$ & 5 & 15 & 15 & 25 & 25 & 35 & 5 & 15 \\
\hline & $18 \%$ & $1.1 \pm 0.4$ & 5 & 15 & 25 & 45 & 15 & 25 & 0 & 5 \\
\hline & $5 \%$ & $1.1 \pm 0.5$ & 5 & 15 & 35 & 55 & 5 & 15 & 0 & 5 \\
\hline & $6 \%$ & \multicolumn{9}{|c|}{ Other Compositions } \\
\hline \multirow{6}{*}{ Sulfide } & $7 \%$ & $0.9 \pm 0.2$ & 15 & 25 & 25 & 45 & 15 & 25 & 0 & 5 \\
\hline & $1 \%$ & $0.6 \pm 0.2$ & 15 & 25 & 25 & 35 & 15 & 25 & 5 & 15 \\
\hline & $6 \%$ & $0.9 \pm 0.4$ & 15 & 25 & 35 & 55 & 5 & 15 & 0 & 5 \\
\hline & $5 \%$ & $0.8 \pm 0.3$ & 25 & 35 & 25 & 55 & 5 & 25 & 0 & 5 \\
\hline & $2 \%$ & $0.7 \pm 0.4$ & 35 & 45 & 45 & 65 & 0 & 5 & 0 & 5 \\
\hline & $9 \%$ & \multicolumn{9}{|c|}{ Other Compositions } \\
\hline
\end{tabular}

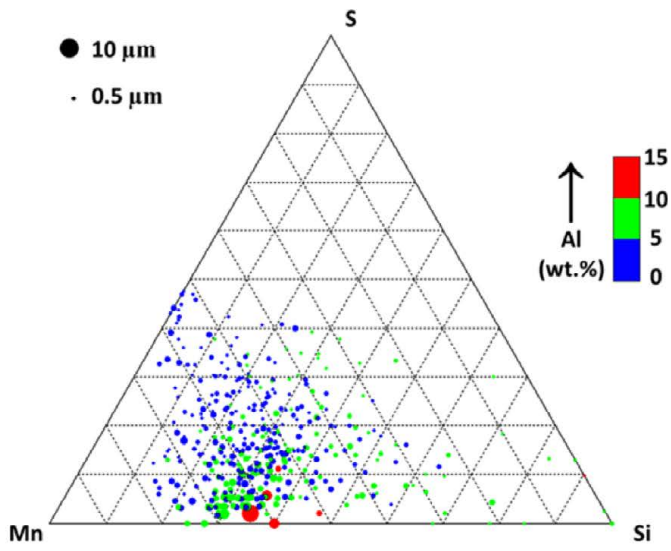

(b) After 5 minutes

Fig. 3. Inclusion composition map after $\mathrm{Fe} 75 \mathrm{Si}+\mathrm{FeMn}$ addition shown on $\mathrm{Mn}-\mathrm{S}-\mathrm{Si}$ ternary with $\mathrm{Al}$ concentration on the color scale for inclusions with low $\mathrm{Ca}(<10 \%)$. (Online version in color.) 
"mixed" and "sulfides" with the sulfur being the distinguishing element. Further among these categories, there are composition ranges for $\mathrm{Mn}, \mathrm{Si}$ and $\mathrm{Al}$. "Other compositions" is the fraction of inclusions of each type that do not fall into the ranges specified. Only those ranges were specified which contained more than $1 \%$ of the total inclusions. The percentage values indicate the population percentage of inclusions in each of these categories. The zero values in the table are the detection limit for the SEM-EDS.

As shown in the ternary diagram (Fig. 3) and confirmed by Table 4, sulfide inclusions were the smallest of all the inclusions. In contrast, the largest inclusions were the $\mathrm{MnO}-$ $\mathrm{SiO}_{2}$ based inclusions with some $\mathrm{Al}_{2} \mathrm{O}_{3}$. Sulfur-rich inclusions were either purely $\mathrm{MnS}$ inclusions or $\mathrm{MnS}$ as predominant phase in oxide inclusions. In case of mixed inclusions, $\mathrm{MnS}$ precipitated on existing oxide inclusions whereas sulfide inclusions formed as a result of sulfur segregation during solidification. As a result, the average inclusion size was higher for mixed inclusions than the sulfide inclusions. $\mathrm{MnS}$ precipitation will first occur in steel on cooling at around $1673 \mathrm{~K}$ (predicted by FactSage). In comparison, the heterogeneous nucleation of $\mathrm{MnS}$ on existing oxide inclusions could take place at higher temperature. Similar behavior has been reported by other researchers. ${ }^{18,20)}$

Typical oxide inclusions formed after $\mathrm{Mn}-\mathrm{Si}$ additions are shown in Fig. 4. Most of these inclusions were spherical in shape owing to the fact that these inclusions were liquid at steelmaking temperature. Al was significant in these inclusions in addition to $\mathrm{Mn}$ and Si. Most of the inclusions

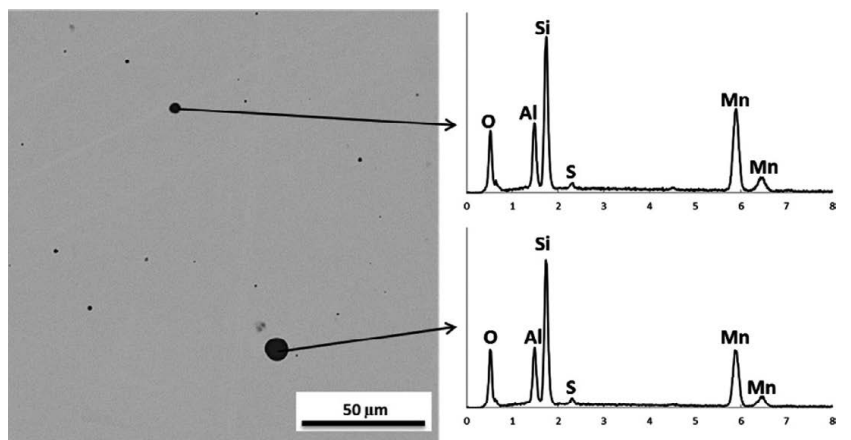

Fig. 4. Typical $\mathrm{Mn}-\mathrm{Si}-\mathrm{Al}-\mathrm{O}$ based oxide inclusion obtained 5 minutes after Fe75Si + FeMn addition. observed were $1-3 \mu \mathrm{m}$ in size (Table 4 ).

Thermodynamic calculations based on the model described earlier (Fig. 2(a)) were performed to determine steel-inclusion equilibrium. Table 5 shows the sample results using steel and inclusion compositions obtained 5 minutes after Fe75Si + FeMn addition (Tables 1 and 4). The inclusion chemistries shown in Table 5 were from four typical ranges of inclusion compositions observed in the steel. "Oxide (1)" and "Oxide (2)" inclusions were chosen as two widely different oxide inclusion compositions within the ranges observed in Table 4. When these inclusions are reacted with steel there is only a small amount of reaction required to equilibrate the inclusions (Table 5), so that despite their different compositions they can be considered to be close to equilibrium with the steel. The calculation for the "Mixed" inclusion shows that the inclusion would lose all its sulfur to steel and its overall mass reduces by about $30 \%$. For the "Sulfide" inclusion this reduction in mass is about $45 \%$. Therefore, the inclusions in the categories "Mixed" and "Sulfide" were not in equilibrium with steel at $1873 \mathrm{~K}$.

Oxide inclusions after the Fe75Si + FeMn addition were predicted to be in equilibrium with steel. For the range of inclusions shown in Table 4, liquid phase (slag) inclusions of composition $\mathrm{MnO}(25-50 \%), \mathrm{SiO}_{2}(30-60 \%), \mathrm{Al}_{2} \mathrm{O}_{3}(5-$ $10 \%)$ and $\mathrm{FeO}(5-10 \%)$ were predicted using the model. Mixed inclusions, were observed as liquid phase inclusions with $\mathrm{MnS}$ and $\mathrm{FeS}$ as significant components. These inclusions were not at equilibrium with the steel at $1873 \mathrm{~K}$. Sulfide inclusions were observed to be liquid phase inclusions with more than $50 \% \mathrm{FeS}$ and $\mathrm{MnS}$. For inclusions with greater than $40 \%$ sulfur content, solid MnS inclusions were also observed. These inclusions were also not at equilibrium with the steel at $1873 \mathrm{~K}$ and were predicted to dissolve completely. This suggests that the mixed and sulfide inclusions formed in steel on cooling.

To study sulfur content in the inclusions of mixed and sulfide type, equilibrium and Scheil-Gulliver cooling studies were done for these inclusions using FactSage. For these calculations, the average chemistries were used. Solid MnS was predicted to form at about $1648 \mathrm{~K}$ for equilibrium cooling. Above this temperature, the maximum sulfur content in the slag in equilibrium with steel was $4 \%$. So, to achieve the amount of $\mathrm{S}$ observed in the inclusions solid MnS precipitation is required. Scheil-Gulliver cooling suggested MnS formation started at about $1673 \mathrm{~K}$ for these inclusions.

Table 5. A representative result for the thermodynamic calculations for steel-inclusion equilibrium at $1873 \mathrm{~K}$.

\begin{tabular}{|c|c|c|c|c|c|c|}
\hline & & & \multicolumn{4}{|c|}{ Inclusion composition (wt.\%) } \\
\hline \multicolumn{2}{|l|}{ Type } & Steel & Oxide (1) & Oxide (2) & Mixed & Sulfide \\
\hline \multirow{4}{*}{ Initial } & $\mathrm{S}$ & 0.01 & 4.5 & 2.7 & 14.5 & 20.9 \\
\hline & $\mathrm{Mn}$ & 0.68 & 21.3 & 28.6 & 28.5 & 23.6 \\
\hline & $\mathrm{Si}$ & 0.13 & 27.9 & 23 & 22.1 & 16.9 \\
\hline & $\mathrm{Al}$ & - & 4.4 & 5.6 & 2.8 & 3.4 \\
\hline \multicolumn{7}{|c|}{$100 \mathrm{~g}$ inclusion $+100000 \mathrm{~g}$ steel } \\
\hline \multirow{7}{*}{ Final } & \multicolumn{2}{|c|}{ Slag weight (g) } & 100.2 & 97.6 & 72.5 & 55.6 \\
\hline & \multicolumn{2}{|l|}{ S } & 0.0 & 0.0 & 0.0 & 0.0 \\
\hline & \multicolumn{2}{|l|}{$\mathrm{Mn}$} & 26.1 & 26.5 & 23.5 & 26.3 \\
\hline & \multicolumn{2}{|l|}{$\mathrm{Si}$} & 21.5 & 20.3 & 22.2 & 20.1 \\
\hline & \multicolumn{2}{|l|}{ Al } & 5.2 & 6.9 & 5.1 & 7.5 \\
\hline & \multicolumn{2}{|c|}{ Prediction } & Equilibrium & Equilibrium & Non-equilibrium & Non-equilibrium \\
\hline & \multicolumn{2}{|c|}{ Change in inclusion } & $\mathrm{FeO}$ gain & MnO loss & Sulfides dissolve & Dissolution \\
\hline
\end{tabular}




\subsection{Effect of FeTi Addition on Mn-Si Based Inclusions}

FeTi additions were made to the Mn-Si containing steel to observe the changes in the existing inclusions. The steel chemistry was measured and inclusion population was analyzed at different time intervals after the FeTi additions as shown in Table 6. Ti content in the steel was highest at one minute after the addition and it decreased with time. This suggests that $\mathrm{Ti}$ content decreased in the steel by removal of Ti-based inclusions.

To plot the ternary diagram for the inclusion population after FeTi addition, Ti, Mn and S were chosen as the key elements based on concentration. The silicon content of

Table 6. Steel chemistry after different additions with $\mathrm{C}-0.032, \mathrm{P}-$ $0.039, \mathrm{~S}-0.009, \mathrm{Cr}-0.064, \mathrm{Ni}-0.04, \mathrm{Al}-<0.001, \mathrm{Cu}-$ 0.042 and $\mathrm{Fe}$ - balance (all values in wt.\%).

\begin{tabular}{llllcc}
\hline Additions & Time & $\mathrm{Si}$ & $\mathrm{Mn}$ & $\mathrm{Ti}$ & $\mathrm{O}$ \\
\hline \multirow{2}{*}{$\mathrm{g} \mathrm{FeTi}$} & $3 \mathrm{~min}$ & 0.12 & 0.66 & 0.014 & 0.017 \\
& $5 \mathrm{~min}$ & 0.12 & 0.66 & 0.011 & 0.0174 \\
& $1 \mathrm{~min}$ & 0.11 & 0.58 & 0.020 & 0.0194 \\
$2 \mathrm{~g} \mathrm{FeTi}$ & $3 \mathrm{~min}$ & 0.12 & 0.58 & 0.021 & 0.0224 \\
& $5 \mathrm{~min}$ & 0.11 & 0.56 & 0.012 & 0.0255 \\
\hline $3 \mathrm{~g} \mathrm{FeTi}$ & $3 \mathrm{~min}$ & 0.10 & 0.52 & 0.022 & 0.0205 \\
& $5 \mathrm{~min}$ & 0.10 & 0.51 & 0.020 & 0.0281
\end{tabular}

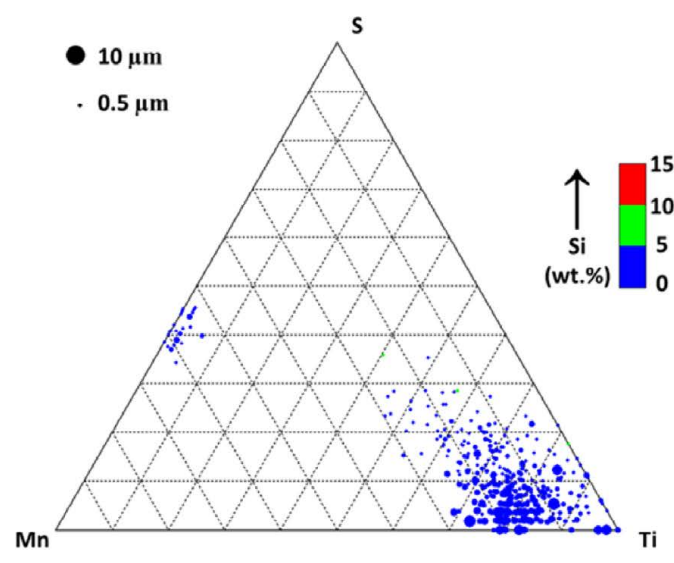

(a) After 1 minute inclusions was selected for the color scale. $\mathrm{Ca}$ and $\mathrm{Al}$ were less significant $(<10 \%)$ components for the majority $(\sim 80 \%)$ of inclusions.

On the Ti-Mn-S ternary plots shown in Fig. 5, inclusions measured after 1 minute, 3 minutes and 5 minutes after the first titanium addition were plotted. From these plots (Fig. 5) it can be seen that immediately after $\mathrm{Ti}$ addition the majority of inclusions contained high concentration of Ti. With increase in mixing time the inclusion compositions tended to move away from high Ti towards $\mathrm{Mn}$.

Before any FeTi addition, the average Si content in the inclusions was around $35 \%$. But after the FeTi addition almost all the inclusions were reduced to less than $10 \% \mathrm{Si}$. In contrast the Mn content of the inclusions decreased from about $50-60 \%$ to about $30 \%$ after the FeTi addition. This suggests that $\mathrm{Ti}$ affects $\mathrm{SiO}_{2}$ more severely than $\mathrm{MnO}$ as $\mathrm{TiO}_{2}$ has a higher affinity for $\mathrm{MnO}$ than $\mathrm{SiO}_{2}$ in the molten oxide phase. $\mathrm{TiO}_{2}$ and $\mathrm{SiO}_{2}$ are immiscible solids below $1823 \mathrm{~K}$ whereas $\mathrm{MnO}$ can form ilmenite and Ti-spinel solid solutions showing higher affinity for $\mathrm{TiO}_{2}{ }^{21,22)}$ Also, $\mathrm{MnS}$ inclusions, containing less than $10 \% \mathrm{Ti}$ or in some cases negligible $\mathrm{Ti}$, were observed, strengthening the hypothesis that these inclusions were formed during solidification. The $\mathrm{Mn}$ to $\mathrm{S}$ ratio in the inclusion is constant as can be seen from the ternary diagrams. This suggests that $\mathrm{MnS}$ precipitation resulted in the formation of these inclusions. With increasing time sulfide inclusions containing $\mathrm{Ti}$ also precipitate.

Some inclusions $(\sim 15 \%)$ with significant amount of $\mathrm{Ca}$ and $\mathrm{Al}(>10 \%)$ were also present in the $\mathrm{Mn}-\mathrm{Si}$ deoxidized steel. These inclusions had low sulfur concentration and were liquid phase (spherical). After the Ti addition these inclusions decreased in number with increasing mixing

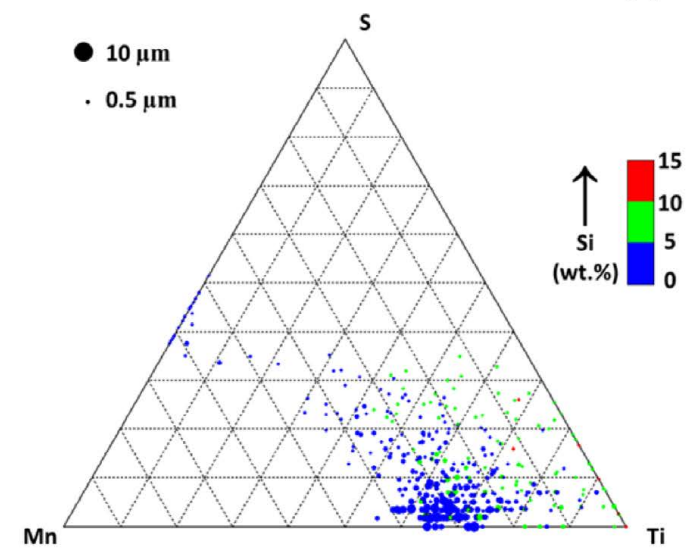

(c) After 5 minutes

Fig. 5. Distribution of inclusion composition (wt.\%) with time after first FeTi addition for inclusions with low Ca and Al $(<10 \%)$. (Online version in color.) 
Table 7. Type of inclusions and their analysis (wt.\%) observed after 5 minutes of first FeTi addition (balance $\mathrm{O}$ with Ca as minor species).

\begin{tabular}{|c|c|c|c|c|c|c|c|c|c|c|c|c|}
\hline \multirow{2}{*}{ Type } & \multirow{2}{*}{ Population $\%$} & \multirow{2}{*}{$\begin{array}{l}\text { Diameter } \\
\quad(\mu \mathrm{m})\end{array}$} & \multicolumn{2}{|c|}{ S } & \multicolumn{2}{|c|}{$\mathrm{Mn}$} & \multicolumn{2}{|c|}{$\mathrm{Ti}$} & \multicolumn{2}{|c|}{$\mathrm{Si}$} & \multicolumn{2}{|c|}{$\mathrm{Al}$} \\
\hline & & & $\min$ & $\max$ & $\min$ & $\max$ & $\min$ & $\max$ & $\min$ & $\max$ & $\min$ & $\max$ \\
\hline \multirow{7}{*}{ Oxide } & $3 \%$ & $0.6 \pm 0.2$ & 0 & 5 & 0 & 5 & 35 & 55 & 5 & 15 & 5 & 15 \\
\hline & $1 \%$ & $0.8 \pm 0.2$ & 0 & 5 & 0 & 5 & 45 & 55 & 0 & 5 & 0 & 5 \\
\hline & $8 \%$ & $2.7 \pm 1.4$ & 0 & 5 & 5 & 25 & 25 & 45 & 5 & 15 & 0 & 5 \\
\hline & $8 \%$ & $1.0 \pm 0.4$ & 0 & 5 & 5 & 15 & 35 & 55 & 0 & 5 & 0 & 5 \\
\hline & $1 \%$ & $1.0 \pm 0.6$ & 0 & 5 & 5 & 15 & 35 & 45 & 5 & 15 & 5 & 15 \\
\hline & $11 \%$ & $1.3 \pm 0.5$ & 0 & 5 & 15 & 25 & 35 & 45 & 0 & 5 & 0 & 5 \\
\hline & $8 \%$ & \multicolumn{11}{|c|}{ Other Compositions } \\
\hline \multirow{6}{*}{ Mixed } & $3 \%$ & $0.6 \pm 0.2$ & 5 & 15 & 0 & 15 & 35 & 45 & 5 & 15 & 5 & 15 \\
\hline & $3 \%$ & $0.7 \pm 0.2$ & 5 & 15 & 5 & 25 & 25 & 45 & 5 & 15 & 0 & 5 \\
\hline & $7 \%$ & $0.8 \pm 0.3$ & 5 & 15 & 5 & 15 & 35 & 55 & 0 & 5 & 0 & 5 \\
\hline & $11 \%$ & $0.8 \pm 0.3$ & 5 & 15 & 15 & 25 & 25 & 45 & 0 & 5 & 0 & 5 \\
\hline & $2 \%$ & $0.9 \pm 0.5$ & 5 & 15 & 25 & 35 & 25 & 35 & 0 & 5 & 0 & 5 \\
\hline & $10 \%$ & \multicolumn{11}{|c|}{ Other Compositions } \\
\hline \multirow{5}{*}{ Sulfide } & $2 \%$ & $0.5 \pm 0.1$ & 15 & 25 & 5 & 15 & 25 & 35 & 5 & 15 & 5 & 15 \\
\hline & $6 \%$ & $0.6 \pm 0.2$ & 15 & 25 & 15 & 35 & 25 & 35 & 0 & 5 & 0 & 5 \\
\hline & $1 \%$ & $0.6 \pm 0.2$ & 15 & 25 & 15 & 25 & 25 & 35 & 5 & 15 & 0 & 5 \\
\hline & $3 \%$ & $0.7 \pm 0.4$ & 35 & 45 & 55 & 65 & 0 & 5 & 0 & 5 & 0 & 5 \\
\hline & $11 \%$ & \multicolumn{11}{|c|}{ Other Compositions } \\
\hline
\end{tabular}

time. This behavior can be attributed to removal due to floatation after coalescence.

The prominent inclusion types observed in the steel 5 minutes after the first FeTi additions are summarized in Table 7. The oxide inclusions formed were the largest in size, whereas the sulfide inclusions were the smallest inclusions similar to the previous observations. Ti and $\mathrm{Mn}$ were the major components of these inclusions.

Typical oxide inclusions formed after the first FeTi additions are shown in Fig. 6. Ti was the major component in these inclusions along with $\mathrm{Mn}, \mathrm{Si}$ and $\mathrm{Al}$. These inclusions were also spherical in shape having regions of varying $\mathrm{Ti}-$ $\mathrm{Mn}-\mathrm{Si}-\mathrm{Al}$ content. This behavior was a result of precipitation of different phases during solidification. The micrograph shows a Ti rich phase precipitated inside the $\mathrm{Ti}-\mathrm{Mn}-$ $\mathrm{Al}-\mathrm{Si}$ inclusion. This was possibly pseudobrookite $\left(\mathrm{Ti}_{3} \mathrm{O}_{5}\right)$, which were also predicted by thermodynamic calculations.

Thermodynamic model described in Table 2(b) was used to study inclusion transformation on FeTi addition. Table 8 shows a sample calculation using inclusion compositions from different categories similar to Table 5. The inclusion chemistries obtained 5 minutes after Fe75Si + FeMn addition (Table 4) and steel composition obtained 1 minute after the first FeTi addition (Table 6) were used. The oxide inclusions transformed by gaining $\mathrm{TiO}_{\mathrm{x}}$ and losing $\mathrm{MnO}, \mathrm{SiO}_{2}$ or both. The drop in Si content of the inclusion was more than the Mn content similar to the behavior observed experimentally. Similar to the previous case mixed and sulfide inclusions were predicted to dissolve at $1873 \mathrm{~K}$.

As the oxide inclusions were reacted with steel containing higher $\mathrm{Ti}(0.02 \%)$, after the first FeTi addition, they were predicted to form $\mathrm{Mn}-\mathrm{Ti}-\mathrm{Si}-\mathrm{Al}$ type oxide inclusions. The equilibrium calculations predicted $\mathrm{TiO}_{\mathrm{x}}$ content of about $30 \%$ with $\mathrm{Mn}$ :Ti ratio close to $1: 1$, whereas, as per the experimental data (Table 6) Mn:Ti ratio was close to $1: 2$ suggesting that complete equilibrium was not achieved after 5 minutes. For the mixed inclusions, the sulfide concentra-

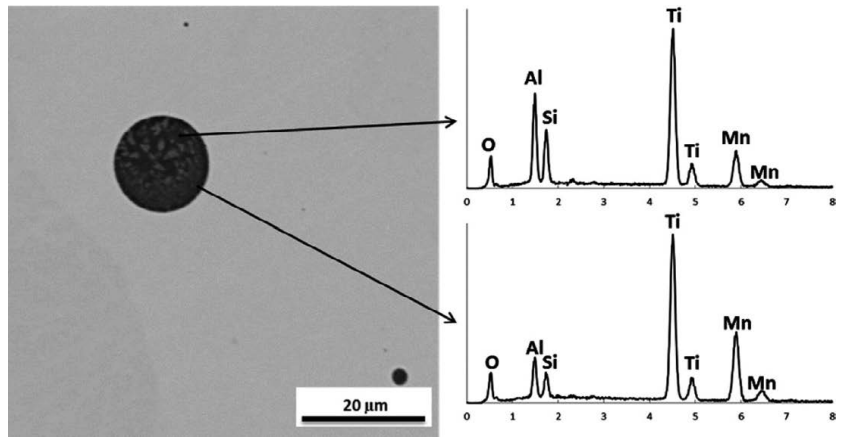

Fig. 6. Typical Ti-Mn-Al-Si-O oxide inclusion, with $\mathrm{Ti}$ rich phase as precipitates, observed 5 minutes after first FeTi addition.

tion of the inclusions dropped to less than $1 \%$ and their predicted behavior (after the sulfide loss) was similar to the oxide inclusions.

After the second FeTi addition, ternary plots were drawn using the same settings as were used for the first additions. Figure 7 shows the mapping of the inclusions on the ternary plot. Similar to the first FeTi addition, the $\mathrm{Ti} /(\mathrm{Ti}+\mathrm{Mn}+\mathrm{S})$ ratio increased towards $100 \%$ immediately after the addition and with time shifted to about $70 \%$ by gaining $\mathrm{Mn}$. This could happen as a result of the following equilibria:

$$
\begin{aligned}
3(\mathrm{MnO})_{\text {(inclusion) }}+2[\mathrm{Ti}] & =\left(\mathrm{Ti}_{2} \mathrm{O}_{3}\right)_{(\text {inclusion })}+3[\mathrm{Mn}] \ldots \\
2(\mathrm{MnO})_{\text {(inclusion) }}+[\mathrm{Ti}] & =\left(\mathrm{TiO}_{2}\right)_{(\text {inclusion })}+2[\mathrm{Mn}] \ldots
\end{aligned}
$$

The high Mn content in the steel drives the reaction (1 and 2 ) in the reverse direction which is aided by the high affinity of $\mathrm{MnO}$ to $\mathrm{TiO}_{2} / \mathrm{Ti}_{2} \mathrm{O}_{3}$. The $\mathrm{SiO}_{2}$ content in the inclusions was negligible just after the second $\mathrm{FeTi}$ addition, although some re-oxidation of silicon took place with time probably 
ISIJ International, Vol. 55 (2015), No. 1

Table 8. A representative result for the thermodynamic calculations to show inclusion transformation on FeTi addition at $1873 \mathrm{~K}$.

\begin{tabular}{|c|c|c|c|c|c|c|}
\hline & & & \multicolumn{4}{|c|}{ Avg. inclusion composition (wt.\%) } \\
\hline \multicolumn{2}{|l|}{ Type } & Steel & Oxide (1) & Oxide (2) & Mixed & Sulfide \\
\hline \multirow{5}{*}{ Initial } & $\mathrm{S}$ & 0.01 & 2.5 & 1.7 & 9 & 32.6 \\
\hline & $\mathrm{Mn}$ & 0.66 & 27.9 & 18.9 & 32.4 & 33.3 \\
\hline & $\mathrm{Si}$ & 0.13 & 26.6 & 29.9 & 20.8 & 13.7 \\
\hline & $\mathrm{Ti}$ & 0.02 & 0.2 & 0.5 & 0.3 & 0.1 \\
\hline & $\mathrm{Al}$ & - & 3.2 & 6.3 & 5.7 & 7 \\
\hline \multicolumn{7}{|c|}{$100 \mathrm{~g}$ inclusion $+100000 \mathrm{~g}$ steel } \\
\hline \multirow{8}{*}{ Final } & \multicolumn{2}{|c|}{ Slag wt. (gram) } & 91.7 & 99.8 & 74.5 & 30.7 \\
\hline & \multicolumn{2}{|l|}{$\mathrm{S}$} & 0.0 & 0.0 & 0.0 & 0.0 \\
\hline & \multicolumn{2}{|l|}{$\mathrm{Mn}$} & 20.7 & 20.1 & 17.7 & 4.0 \\
\hline & \multicolumn{2}{|l|}{$\mathrm{Si}$} & 11.5 & 11.4 & 8.2 & 1.2 \\
\hline & \multicolumn{2}{|l|}{$\mathrm{Ti}$} & 19.8 & 18.2 & 23.2 & 31.5 \\
\hline & \multicolumn{2}{|l|}{$\mathrm{Al}$} & 4.5 & 7.2 & 8.7 & 19.0 \\
\hline & \multicolumn{2}{|c|}{ Prediction } & Equilibrium & Equilibrium & Non-equilibrium & Non-equilibrium \\
\hline & \multicolumn{2}{|c|}{ Change in inclusion } & $\begin{array}{c}\mathrm{MnO}-\mathrm{SiO}_{2} \text { Loss/ } \\
\mathrm{TiO}_{\mathrm{x}} \text { gain }\end{array}$ & $\begin{array}{l}\mathrm{SiO}_{2} \text { loss/ } \\
\mathrm{TiO}_{x} \text { gain }\end{array}$ & Sulfides dissolve & Dissolution \\
\hline
\end{tabular}

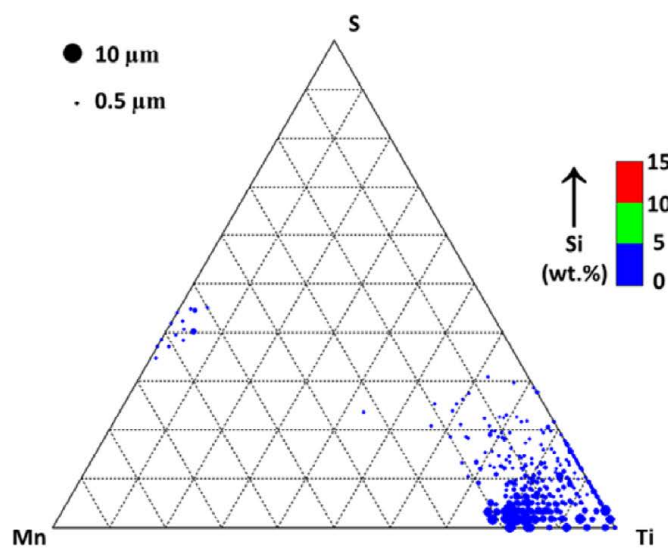

(a) After 1 minute

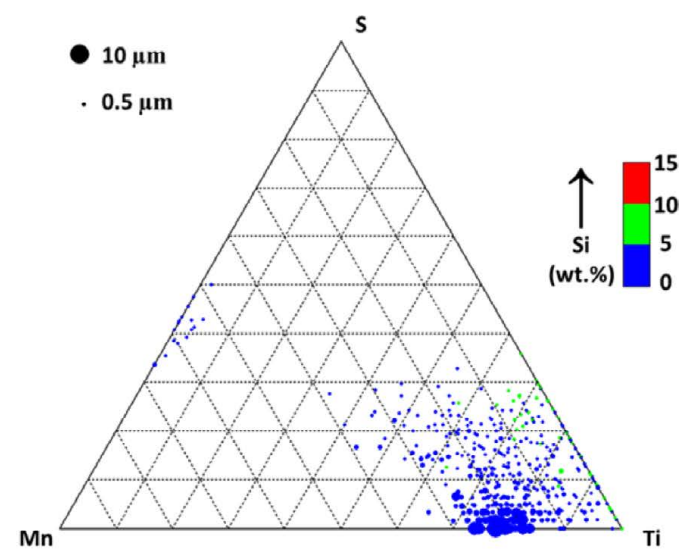

(b) After 3 minutes

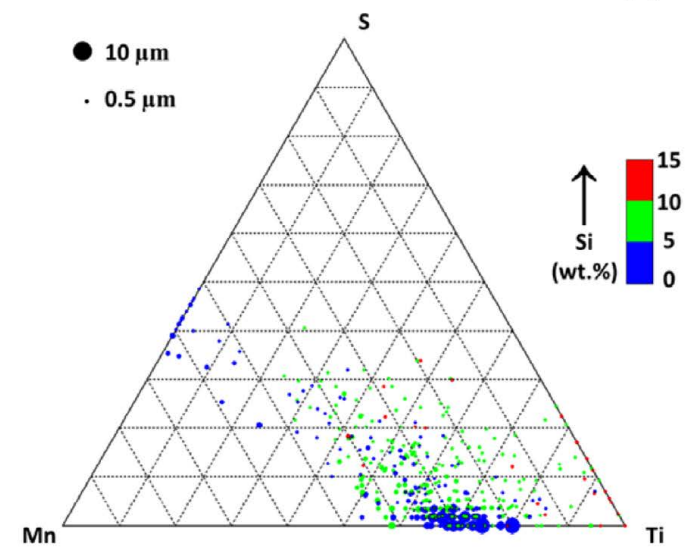

(c) After 5 minutes

Fig. 7. Distribution of inclusion composition (wt.\%) with time after second FeTi addition for inclusions with low Ca and $\mathrm{Al}(<10 \%)$. (Online version in color.)

during multiple sampling steps which caused an increase in the $\mathrm{Si}$ content in the inclusions observed in the final sample (Fig. 7). A gain in total oxygen content was observed with subsequent sampling steps as shown in Table 6. An example of $\mathrm{SiO}_{2}$ rich inclusion is shown in Fig. 8. Also, the MnS behavior was similar, to the previous case, in addition to the formation of some titanium sulfide inclusions. Other inclusions, richer in $\mathrm{Ca}$ and $\mathrm{Al}(>10 \%)$ further decreased after the 
second FeTi addition.

The prominent inclusion types observed in the steel, 5 minutes after the second FeTi additions are summarized in Table 9. Similar to the previous case, the oxide inclusions formed were the largest in size, whereas the sulfide or mixed inclusions were the smallest. Some oxide inclusions with only $\mathrm{Ti}$ and $\mathrm{Mn}$ were observed to have an average diameter of about $5 \mu \mathrm{m}$ (Fig. 7).

Similar to the previous case, inclusion transformation due to the second FeTi addition was studied thermodynamically using the model shown in Fig. 2(b). Inclusion chemistries obtained 5 minutes after the first FeTi addition (Table 7) were reacted to steel composition obtained 1 minute after the second FeTi addition (Table 6). Oxide inclusions were

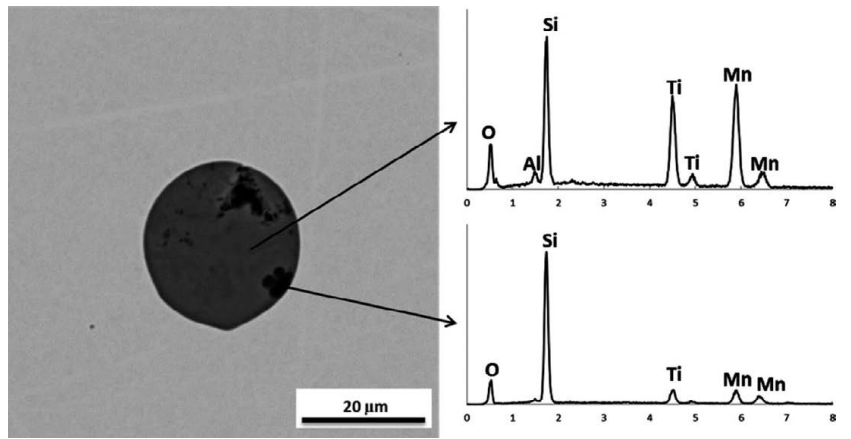

Fig. 8. $\mathrm{SiO}_{2}$ precipitate in $\mathrm{Si}-\mathrm{Mn}-\mathrm{Ti}-\mathrm{Al}-\mathrm{O}$ inclusion observed 5 minutes after second FeTi addition.
Table 9. Type of inclusions and their analysis (wt.\%) observed after 5 minutes of second $\mathrm{FeTi}$ addition (balance $\mathrm{O}$ with $\mathrm{Al}$ and $\mathrm{Ca}$ as minor species).

\begin{tabular}{|c|c|c|c|c|c|c|c|c|c|c|}
\hline \multirow{2}{*}{ Type } & \multirow{2}{*}{$\begin{array}{c}\text { Population } \\
\%\end{array}$} & \multirow{2}{*}{$\begin{array}{c}\text { Diameter } \\
(\mu \mathrm{m})\end{array}$} & \multicolumn{2}{|c|}{$\mathrm{S}$} & \multicolumn{2}{|c|}{$\mathrm{Mn}$} & \multicolumn{2}{|c|}{$\mathrm{Ti}$} & \multicolumn{2}{|c|}{$\mathrm{Si}$} \\
\hline & & & $\min$ & $\max$ & $\min$ & $\max$ & $\min$ & $\max$ & $\min$ & $\max$ \\
\hline \multirow{6}{*}{ Oxide } & $2 \%$ & $0.6 \pm 0.1$ & 0 & 5 & 0 & 5 & 35 & 45 & 5 & 15 \\
\hline & $5 \%$ & $1.7 \pm 1.4$ & 0 & 5 & 5 & 15 & 35 & 55 & 0 & 5 \\
\hline & $7 \%$ & $0.7 \pm 0.2$ & 0 & 5 & 5 & 15 & 35 & 45 & 5 & 15 \\
\hline & $8 \%$ & $1.0 \pm 0.4$ & 0 & 5 & 15 & 25 & 25 & 45 & 5 & 15 \\
\hline & $21 \%$ & $1.9 \pm 1.5$ & 0 & 5 & 15 & 25 & 35 & 45 & 0 & 5 \\
\hline & $7 \%$ & \multicolumn{9}{|c|}{ Other Compositions } \\
\hline \multirow{6}{*}{ Mixed } & $2 \%$ & $0.5 \pm 0.1$ & 5 & 15 & 0 & 5 & 35 & 45 & 5 & 15 \\
\hline & $6 \%$ & $0.6 \pm 0.2$ & 5 & 15 & 5 & 15 & 25 & 45 & 0 & 5 \\
\hline & $1 \%$ & $0.5 \pm 0.1$ & 5 & 15 & 5 & 15 & 35 & 45 & 0 & 5 \\
\hline & $7 \%$ & $0.7 \pm 0.2$ & 5 & 15 & 15 & 35 & 25 & 45 & 0 & 5 \\
\hline & $12 \%$ & $0.7 \pm 0.2$ & 5 & 15 & 25 & 45 & 25 & 45 & 5 & 15 \\
\hline & $4 \%$ & \multicolumn{9}{|c|}{ Other Compositions } \\
\hline \multirow{5}{*}{ Sulfide } & $5 \%$ & $0.5 \pm 0.1$ & 15 & 25 & 5 & 35 & 25 & 35 & 5 & 15 \\
\hline & $2 \%$ & $0.5 \pm 0.2$ & 15 & 25 & 15 & 35 & 25 & 35 & 0 & 5 \\
\hline & $2 \%$ & $0.7 \pm 0.3$ & 15 & 25 & 25 & 45 & 15 & 25 & 0 & 5 \\
\hline & $1 \%$ & $0.8 \pm 0.4$ & 35 & 45 & 55 & 65 & 0 & 5 & 0 & 5 \\
\hline & $8 \%$ & \multicolumn{9}{|c|}{ Other Compositions } \\
\hline
\end{tabular}

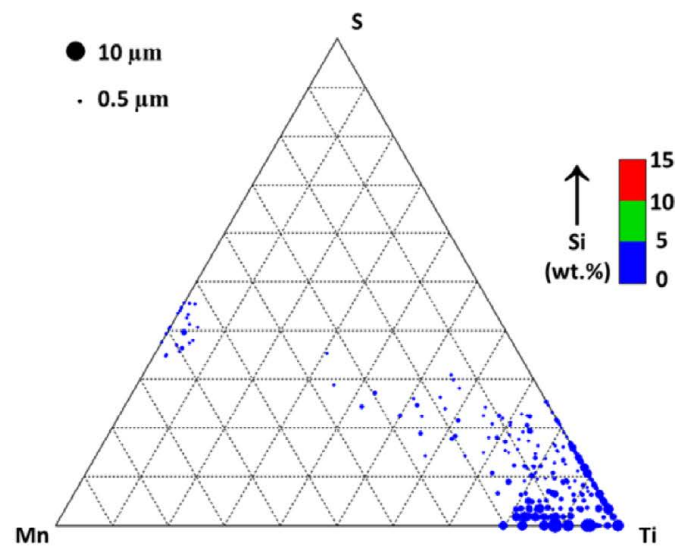

(b) After 3 minutes

(a) After 1 minute

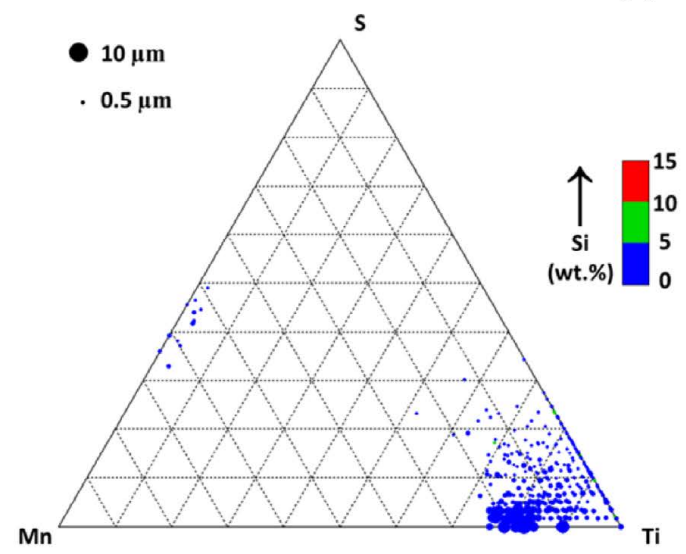

(c) After 5 minutes

Fig. 9. Distribution of inclusion composition (wt.\%) with time after third FeTi addition for inclusions with low $\mathrm{Ca}$ and $\mathrm{Al}$ $(<10 \%)$. (Online version in color.) 
predicted to gain $\mathrm{Ti}$ and lose $\mathrm{Si}$ to steel and form liquid phase inclusions with about $5-10 \% \mathrm{Mn}$ and $\mathrm{Al}$ depending on their initial composition. These inclusions were predicted to have about $80 \% \mathrm{TiO}_{\mathrm{x}}$ and less than $5 \% \mathrm{FeO}$. The $\mathrm{SiO}_{2}$ content was predicted to be negligible $(<1 \%)$. The ternary plot drawn after the second FeTi addition shows this behavior after 1 and 3 minutes of the addition (Figs. 7(a) and 7(b)). The equilibrium calculations confirm that re-oxidation was the source of the Si rich inclusions observed experimentally (Fig. 7(c)).

From the ternary plots (Fig. 9), the changes in inclusion chemistry with time after the third FeTi addition can be observed. Immediately after the FeTi addition the Si content of the inclusions dropped to zero which increased to less than $5 \%$ with time. The $\mathrm{Ti} /(\mathrm{Ti}+\mathrm{Mn}+\mathrm{S})$ ratio in the inclusions also dropped with time and after 5 minutes most of the inclusions had $\mathrm{Ti} /(\mathrm{Ti}+\mathrm{Mn}+\mathrm{S})$ ratios between $75 \%$ and $90 \%$. The gain of $\mathrm{Mn}$ to $\mathrm{Ti}$ rich inclusions was significantly less compared to previous additions, suggesting that $\mathrm{TiO}_{2} / \mathrm{Ti}_{2} \mathrm{O}_{3}$ $\left(\mathrm{TiO}_{\mathrm{x}}\right)$ saturation was achieved in the inclusions. Further, the change in inclusion composition with time was not as significant as in the previous cases. The $\mathrm{S}$ rich inclusions were predominantly $\mathrm{MnS}$.

The prominent inclusion types observed in the steel 5 minutes after the third FeTi additions are summarized in

Table 10. Type of inclusions and their analysis (wt.\%) observed after 5 minutes of third FeTi addition (balance $\mathrm{O}$ with $\mathrm{Ca}$ and $\mathrm{Si}$ as minor species).

\begin{tabular}{|c|c|c|c|c|c|c|c|c|c|c|}
\hline \multirow{2}{*}{ Type } & \multirow{2}{*}{$\begin{array}{c}\text { Population } \\
\%\end{array}$} & \multirow{2}{*}{$\begin{array}{l}\text { Diameter } \\
(\mu \mathrm{m})\end{array}$} & \multicolumn{2}{|c|}{$\mathrm{S}$} & \multicolumn{2}{|c|}{$\mathrm{Mn}$} & \multicolumn{2}{|c|}{$\mathrm{Ti}$} & \multicolumn{2}{|c|}{$\mathrm{Al}$} \\
\hline & & & $\min$ & $\max$ & $\min$ & $\max$ & $\min$ & $\max$ & $\min$ & $\max$ \\
\hline \multirow{5}{*}{ Oxide } & $15 \%$ & $0.8 \pm 0.3$ & 0 & 5 & 0 & 5 & 45 & 65 & 0 & 5 \\
\hline & $3 \%$ & $0.8 \pm 0.4$ & 0 & 5 & 0 & 5 & 45 & 55 & 5 & 15 \\
\hline & $27 \%$ & $1.9 \pm 1.5$ & 0 & 5 & 5 & 15 & 45 & 55 & 0 & 5 \\
\hline & $3 \%$ & $3.8 \pm 2.9$ & 0 & 5 & 5 & 15 & 45 & 55 & 5 & 15 \\
\hline & $4 \%$ & \multicolumn{9}{|c|}{ Other Compositions } \\
\hline \multirow{4}{*}{ Mixed } & $17 \%$ & $0.6 \pm 0.2$ & 5 & 15 & 0 & 5 & 45 & 65 & 0 & 5 \\
\hline & $6 \%$ & $0.5 \pm 0.1$ & 5 & 15 & 0 & 5 & 45 & 55 & 5 & 15 \\
\hline & $11 \%$ & $0.7 \pm 0.3$ & 5 & 15 & 5 & 15 & 35 & 55 & 0 & 5 \\
\hline & $3 \%$ & \multicolumn{9}{|c|}{ Other Compositions } \\
\hline \multirow{3}{*}{ Sulfide } & $1 \%$ & $0.4 \pm 0.1$ & 15 & 25 & 0 & 5 & 45 & 55 & 0 & 5 \\
\hline & $1 \%$ & $0.7 \pm 0.5$ & 35 & 45 & 55 & 65 & 0 & 5 & 0 & 5 \\
\hline & $9 \%$ & \multicolumn{9}{|c|}{ Other Compositions } \\
\hline
\end{tabular}

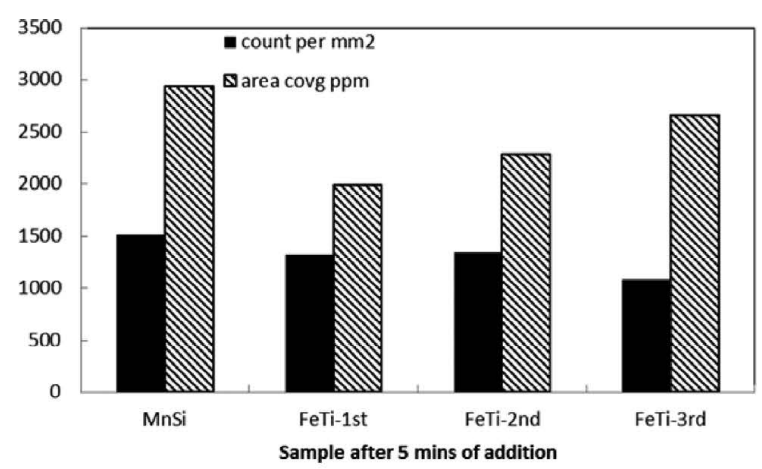

(a)
Table 10. Almost all the Ti-based inclusions contained small amounts of $\mathrm{Mn}$ or $\mathrm{Al}$ or both. A few pure $\mathrm{TiO}_{\mathrm{x}}$ inclusions were also observed. The Si content in all the inclusions was reduced to less than $5 \%$. The amount of $\mathrm{Al}$ or $\mathrm{Mn}$ in the inclusions depended on the initial composition of the inclusions. With increasing $\mathrm{Ti}$, all the $\mathrm{Mn}$ can be removed from some of the inclusions. MnS precipitation on the existing $\mathrm{Ti}-\mathrm{Al}-\mathrm{O}$ inclusions during solidification could be the cause of the higher Mn content in the inclusions. Typical inclusions formed after the third FeTi addition, were similar in morphology to the inclusions observed earlier except for their higher Ti content.

As per the thermodynamic calculations, when the oxide type inclusions were reacted with steel of higher Ti concentration (third FeTi addition) liquid slag inclusions with about $85 \% \mathrm{TiO}_{\mathrm{x}}$ content were predicted confirming the experimental data represented in Fig. 9. $\mathrm{MnO}$ and $\mathrm{Al}_{2} \mathrm{O}_{3}$ content were predicted to be around $5 \%$. In the slag phase, $\mathrm{SiO}_{2}$ content was predicted to be less than $1 \%, \mathrm{MnO}$ was around $5 \%$ and $\mathrm{TiO}_{\mathrm{x}}$ was $85 \%$. Oxide inclusions that initially had only $\mathrm{Ti}$ and $\mathrm{Mn}$ were predicted to form solid $\mathrm{Ti}_{3} \mathrm{O}_{5}$.

Overall with increasing FeTi addition, the $\mathrm{TiO}_{\mathrm{x}}$ content increased in the inclusions from $30 \%$ to $85 \%$. The inclusions were predicted to form liquid phase at $1873 \mathrm{~K}$ and solid $\mathrm{Ti}_{3} \mathrm{O}_{5}$ phase was predicted only after the third FeTi addition. $\mathrm{Ti}$ addition affected the $\mathrm{Si}$ and $\mathrm{Mn}$ content of the inclusions but the $\mathrm{Al}$ content remained constant. The $\mathrm{MnO}$ in inclusions decreased gradually with each step whereas the $\mathrm{SiO}_{2}$ content was calculated to drop to less than $1 \%$ after the first FeTi addition. Sulfide content less than $1 \%$ was in equilibrium with steel at $1873 \mathrm{~K}$ and would increase only on cooling.

The oxide inclusions increased from about 25\% (after $\mathrm{Fe} 75 \mathrm{Si}+\mathrm{FeMn}$ addition) to $45 \%$ (after third FeTi addition) showing that all the inclusions were not affected by Mn and $\mathrm{S}$ segregation. Presumably the oxide inclusions were not "pushed" by the solid/liquid interface, and so were isolated in solid steel early in the solidification process. Many inclusions were present in the solidified steel before significant segregation occurred in the remaining liquid and therefore remained as oxide. The mixed/sulfide inclusions must have formed at lower temperatures and in inter-dendritic regions with $\mathrm{Mn}$ and $\mathrm{S}$ segregation. Hence only a fraction of the inclusions are of the types mixed and sulfide. The high fraction of oxide inclusions after the third FeTi addition and hence the formation of solid $\mathrm{Ti}_{3} \mathrm{O}_{5}$ inclusions suggests that too much FeTi was added. So, to achieve inclusion modification (without any solid inclusions), adding a small fraction of FeTi in steps would be more effective.

After each ferro-alloy addition and a mixing time of 5 minutes, number of inclusions and coverage area were cal-

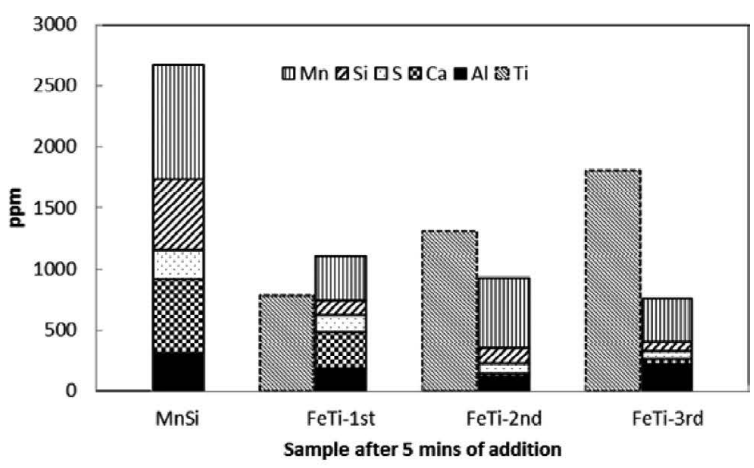

(b)

Fig. 10. Inclusion variations at different stages in the experiment: (a) inclusion count per $\mathrm{mm}^{2}$ and area of inclusions per $\mathrm{mm}^{2}$ (coverage) and (b) amount (in ppm) of each element in the inclusions. 
culated and shown in Fig. 10(a). From the plot it can be observed that the inclusion count dropped after the first FeTi addition along with the inclusion coverage. This behavior would be a result of removal of larger inclusions. After the second FeTi addition, the inclusion count increased slightly with a greater increase in the inclusion coverage indicating increase in inclusion size. Increase in inclusion size can be attributed to coalescence of liquid inclusions. The inclusions at this stage were smaller in number and coverage than those observed after the initial Fe75Si + FeMn addition. After the third addition, the number of inclusions dropped but the coverage increased owing to similar coalescence behavior. The average inclusion size would be much larger compared to the inclusions observed after Fe75Si + FeMn addition. This behavior suggested that the inclusions were agglomerating to form larger inclusions.

Figure 10(b) shows the amount of the different elements in the inclusions divided by the total elements in the samples in ppm values at 5 minutes after different ferro-alloy additions. It was observed that the addition of FeTi resulted in drop of $\mathrm{Mn}$ and Si content of the inclusions. The drop was more predominant in case of Si than $\mathrm{Mn}$ as explained earlier. $\mathrm{Mn}$ and $\mathrm{Si}$ content in the inclusions would be replaced by the Ti from the FeTi added which was also confirmed by the thermodynamic calculations. Thermodynamic calculations showed no change in the $\mathrm{Al}$ and $\mathrm{Ca}$ component of inclusions due to the FeTi addition. The sulfur content of the inclusions also dropped with addition of FeTi.

\section{Conclusions}

In the present study, $\mathrm{Mn}-\mathrm{Si}-\mathrm{Al}-\mathrm{O}$ based solid/liquid inclusions were modified with $\mathrm{Ti}$ additions. Experiments and thermodynamic modeling was performed to assess the effects of Ti addition on inclusions in Mn-Si killed steel. Inclusion composition was plotted using a quaternary system to observe inclusion evolution with time. Inclusions were divided into categories based on their compositions and these compositions further used to study thermodynamic equilibrium with steel. The following conclusions can be drawn from this study:

(1) FeTi addition transformed all the existing inclusions in the $\mathrm{Mn}-\mathrm{Si}$ killed steel by enriching the inclusions with $\mathrm{Ti}$ to form liquid inclusions.

(2) Both $\mathrm{Si}$ and $\mathrm{Mn}$ were removed from the inclusions with FeTi addition. Si removal was more predominant than $\mathrm{Mn}$. Si content was reduced to less than 5\% after the second FeTi addition and was almost negligible after the third addition. However, Mn was not removed completely. This behavior can be attributed to the higher affinity of Ti-oxide for $\mathrm{MnO}$ than $\mathrm{SiO}_{2}$. FeTi addition should be added in small fraction to achieve effective modification with the inclusions remaining liquid.

(3) The Al content in the inclusions did not change compared to the initial composition. Most of the inclusions formed at temperature were $\mathrm{Ti}-\mathrm{Al}-\mathrm{Mn}-\mathrm{O}$ based complex inclusions. These inclusions precipitated Ti-rich phase on solidification. MnS also precipitates on these inclusions.

(4) Sulfide inclusions were formed as a result of $\mathrm{MnS}$ formation during solidification. This phase can precipitate on existing oxide inclusions to form mixed inclusions, since $\mathrm{MnS}$ was observed in inclusions both as a separate phase or in solution. Due to changes in composition on cooling and solidification (with $\mathrm{Mn}$ and $\mathrm{S}$ segregation), about 1/3rd of the inclusions were mixed and about $1 / 6$ th were sulfides. The relative amounts of these inclusions would depend on the relative oxygen and sulfur levels in the steel.

(5) Ti addition can be used to modify inclusions in $\mathrm{Si}-$ Mn killed steels especially low Mn steels where solid $\mathrm{SiO}_{2}$ inclusions are a major cause of concern.

\section{Acknowledgment}

The authors would like to express their sincere appreciation and gratitude for the late Professor Kent D. Peaslee for providing guidance and support for this research and for always being an inspiration for us.

\section{REFERENCES}

1) L. Zhang and B. G. Thomas: ISIJ Int., 43 (2003), 271.

2) K. Rackers and B. G. Thomas: 78th Steelmaking Conf. Proc., Iron and Steel Society, Warrendale, PA, (1995), 723.

3) L. Zhang and B. G. Thomas: XXIV National Steelmaking Symp., Mexico, (2003), 138

4) L. Zhang, S. Taniguchi and K. Cai: Metall. Mater. Trans. B, 31B (2000), 253.

5) L. Zhang and S. Taniguchi: Int. Mater. Rev., 45 (2000), No. 2, 59.

6) B. H. Yoon, K. H. Heo, J. S. Kim and H. S. Sohn: Ironmaking Steelmaking, 29 (2002), 214.

7) Y. Murakami, S. Kodama and S. Konuma: Int. J. Fatigue, 11 (1989), 291.

8) M. Lind and L. Holappa: Metall. Mater. Trans. B, 41B (2010), 359.

9) R. B. Tuttle, J. D. Smith and K. D. Peaslee: Metall. Mater. Trans. B, 36B (2005), 885.

10) S. Chakraborty and Y. Sahai: Metall. Mater. Trans. B, 23B (1992), 135

11) L. Zhang, J. Aoki and B. G. Thomas: Metall. Mater. Trans. B, 37B (2006), 361

12) B. G. Thomas, A. Dennisov and H. Bai: 80th Steelmaking Conf., ISS, Warrendale, PA, (1997), 375.

13) Y. Miki, B. G. Thomas, A. Denissov and Y. Shimada: Iron Steelmaker, 24 (1997), 31

14) E. T. Turkdogan: Fundamentals of Steelmaking, The Institute of Materials, London, (1996), 285.

15) E. B. Pretorius and R. Marr: 53rd Electric Furnace Conf. Proc., Iron and Steel Society, Warrendale, PA, (1995), 407.

16) C. W. Bale, P. Chartrand, S. A. Degterov, G. Eriksson, K. Hack, R. Ben Mahfoud, J. Melancon, A. D. Pelton and S. Petersen: Calphad, 26 (2002), 189

17) Y. Kanga, I. Jung and H. Lee: Calphad, 30 (2006), 226.

18) H. Amitani, K. Morita and N. Sano: ISIJ Int., 36 (1996), S26.

19) Z. T. Ma and D. Janke: Acta Metall. Sin., 11 (1998), 79.

20) H. Kim, H. Lee and K. Oh: ISIJ Int., 42 (2002), No. 12, 1404

21) M. Kiviö and L. Holappa: Metall. Mater. Trans. B, 43B (2012), 233.

22) G. Eriksson and A. D. Pelton: Metall. Mater. Trans. B, 24B (1993), 795. 